\title{
RESPONSABILIDADE CIVIL, PENAL E ÉTICA DOS MÉDICOS
}

Artur Udelsmann

Departamento de Anestesiologia da Faculdade de Ciências Médica da Universidade Estadual de Campinas,SP

RESUMO - Nos últimos anos, os médicos têm sido alvo de processos indenizatórios, criminais e éticos com freqüência cada vez maior. A Medicina é uma profissão muito visada, não somente em razão dos riscos que comporta, mas também, em alguns casos, por uma visão equivocada do Poder Judiciário sobre as obrigações dos médicos. As decisões nos processos éticos dos Conselhos Regionais de Medicina repercutem na justiça comum, e por isso devem ser seguidas com bastante atenção. 0 objetivo desta revisão é dar uma visão ampla, do ponto de vista de um médico-advogado, dos processos envolvendo responsabilidade civil, penal e ética e tentar torná-los compreensíveis aos médicos.

Após breve introdução histórica, são abordadas as causas de responsabilidade civil e os artigos legais que the dão base. As responsabilidades do médico, do hospital e dos planos de saúde são vistas separadamente, bem como os mecanismos de indenização. 0 s crimes possíveis de ocorrer no exercício da Medicina são descritos, suas penas e a relação direta existente entre crime e a indenização é demonstrada. É feita a descrição da natureza administrativa do processo ético, chamando a atenção para o fato do caráter legal de suas penas, que com frequêencia, serve de base para as decisões da justiça comum.

A prevenção ainda é o melhor remédio para fazer face ao problema; 0 bom exercício da Medicina e a boa relação médico-paciente ainda são as melhores soluções para minimizar as repercussões de tais ações. É conveniente que os médicos tenham noções dos mecanismos jurídicos de tais demandas, mas não devem nunca tomar iniciativas de defesa sem antes consultar um advogado.

Unitermos: Médico. Responsabilidade: civil, penal, ética.
INTRODUÇÃO

O exercício da Medicina, até um passado historicamente recente, era cercado de uma aura de divindade e não se discutiam os desígnios dos esculápios, pois estes eram tidos somente como intermediários da vontade divina. Mesmo assim, já no Código de Hammurabi da Babilônia do séc. XVIII a.C. havia regras que previam penas aos médicos em caso de erros!. Com a evolução dos conhecimentos, a arte da Medicina foi se tornando ciência, e com isso a sociedade passou a exigir dos médicos condutas científicas e reparação por eventuais erros cometidos. A socieda-

*Correspondência:

Av. Prof. Atílio Martini, 213 - CEP: 13084-210

Campinas - SP - telefone: (19) 3289.4651

e-mail: artur@fcm.unicamp.br de muito evoluiu desde então, até chegarmos aos tempos de hoje, onde o exercício da Medicina em nosso país tornou-se quase uma atividade de risco. Não bastassem as inúmeras dificuldades das políticas governamentais de saúde, os conflitos com os planos e seguros de saúde, acrescentese, mais recentemente, a tendência à institucionalização da "indústria da indenização", cópia deformada de modelos existentes em outros países mais evoluídos. Médicos não têm formação jurídica, mas deveriam começar a olhar a questão com interesse se pretendem continuar a exercer a profissão e sobreviver no mercado de trabalho. $\mathrm{O}$ objetivo da seguridade social moderna é, acertadamente, o de estender os cuidados à saúde e os cuidados médicos a toda a população, mas esta, freqüentemente, confunde o direito à seguridade com o direito à cura e tende, atualmente, a exigir indenizações quando seus objetivos não são atingidos, encorajada pela mídia sensacionalista.

\section{Objetivo}

O objetivo deste trabalho é apresentar as implicações médico-legais na área cível, penal e ética do exercício da Medicina em nosso país, a legislação que rege a prática da profissão do médico liberal, a do médico empregado de entidade privada ou ainda do servidor público. Mostramos ainda as leis que salvaguardam e as que responsabilizam o médico na sua prática profissional diária; propomos também aos colegas médicos algumas soluções preventivas no caso dos mesmos se verem confrontados a tais situações. 


\section{Responsabildade Civil}

A noção da responsabilidade civil, ou seja, a da necessidade de se compensar um eventual erro cometido, surgiu com a discussão sobre o Direito Natural, este mais antigo do que a própria Medicina, e através do qual se reconhecem direitos inalienáveis do ser humano, como o direito à vida, à felicidade e à liberdade; toda vez que esses direitos fossem ultrajados criava-se o direito a uma reparação. No Direito moderno essa reparação tem natureza pecuniária.

Inicialmente, o paciente é, indiscutivelmente, o último juiz da sua própria saúde, e não se tratando de uma emergência, só ele pode ter a última palavra sobre o interesse ou não de empreender determinado tratamento, sopesando os riscos e beneficios. A esse respeito, diz o artigo 94 do Código Civil (CC): "Nos atos bilaterais, o silêncio intencional de uma das partes a respeito de fato ou qualidade que a outra parte haja ignorado, constitui omissão dolosa, provando-se que sem ela não se teria celebrado o contrato". Disto já tiramos uma primeira lição: é imperativo que o paciente seja previamente esclarecido, em linguagem a ele compreensível, sobre sua patologia, os limites do tratamento proposto e eventuais reações adversas, além das possíveis complicações.

A responsabilidade civil do profissional da Medicina deriva da culpa no sentido amplo, esta engloba o dolo, ou seja, a vontade premeditada de causar dano, e a culpa em sentido estrito, ambos também previstos no Direito Penal. Inicialmente, há que se verificar a real ocorrência de algum dano ao paciente. Entende-se por dano a ofensa a bens ou interesses alheios protegidos pela ordem jurídica; resumidamente, há uma afronta à norma jurídica, há o caráter de antijuridicidade e um prejúzo. O dano pode ser patrimonial, de ordem financeira, ou extrapatrimonial (dano moral, por exemplo) e os dois podem ser cumuláveis². Havendo dano, há que se auferir a noção do nexo de causalidade, ou seja, é imperativo que se estabeleça que a lesão foi realmente causada por ação ou omissão do médico e sua culpa. Se um paciente sofre uma anóxia durante a anestesia com lesão cerebral e comprovase que houve descuido do anestesista, configura-se um dano, o nexo de causalldade e a culpa, a indenização será então devida. A essência da culpa está na previsibilidade: se o resultado desfavorável era previsível e não foi evitado, há culpa. Se o resultado desfavorável, nas circunstâncias do caso, não era possível de ser previsto, estamos face às excludentes de culpabilidade e são elas o caso fortuitoe o de força maior, previstas no artigo 1058 $\S$ único do CC, quando então o médico não poderá ser responsabilizado ${ }^{3}$. Simplificando, denomina-se caso fortuito aquele estranho à vontade do homem, imprevisível, inevitável ${ }^{4}$ (choque anafilactóide em indivíduo sem antecedentes), e o de força maior aquele absolutamente necessário, que cause algum dano, porém se não tivesse sido praticado, daria lugar a dano maior ainda (histerectomia de urgência em hemorragia pós-parto causando esterilidade). Havendo dano, sem as excludentes de culpabilidade, o direito à indenização é certo segundo o caput do artigo 159 do CC que diz: "Aquele que, por ação ou omissão voluntária, negligência ou imprudência, violar direito, ou causar prejuízo a outrem, fica obrigado a reparar o dano". Mais especificamente, o artigo 1545 do mesmo código esposou inteiramente a teoria da culpa: "Os médicos, cirurgiôes, farmacêuticos, parteiras e dentistas são obrigados a satisfazer o dano, sempre que da imprudência, negligência ou imperícia, em atos profissionais, resultar morte, inabilitaçãa de servir, ou ferimento". A culpa em sentido estrito tem três vertentes: a imprudência, a negligência e a imperícia. A imprudência se caracteriza pela prática de atos de risco não justificados, afoitos, sem a cautela necessária. A negligência é um ato omissivo, quando o médico deixa de observar regra profissional já bem estabelecida e reconhecida pelos colegas da especialidade. E a imperícia é o despreparo, a prática de determinados atos sem os conhecimentos técnico-científicos necessários para realizá-los. Mais recentemente, a lei 8.078/90 (Código de Defesa do Consumidor), no seu artigo I4, § $4^{\circ}$ confirmou a necessidade da verificação da culpa dos profissionais liberais, contrariamente aos demais fornecedores de serviços, como exigência para reparação de dano em caso de erro médico: "A responsabilidade pessoal dos profissionais liberais será apurada mediante a verificação da culpa". A aferição da culpa do médico obedecerá então a uma equação com três incógnitas: açãa ou omissão culposa + relaçãa de causalidade + dano $=$ responsabilidade civil indenizatória6.

O Direito entende que, na relação entre o médico e o paciente, há o estabelecimento de um contrato quando do acordo para prestaçãa de serviços, mesmo que este não tenha sido firmado em documento; neste último caso, o contrato é denominado "tácito". Mas essa relação poderá também ser extra-contratual quando não houver acordo anterior, como, por exemplo, quando o paciente procura um hospital ou Pronto-Socorro e é atendido pelo médico de plantão ou no caso de socorro a um acidentado na via pública. Em razão dessa relação, contratual ou extra-contratual, criam-se obrigações; as obrigações do médico são de informaçãa, cuidados terapêuticos e de abstenção de abuso ou desvio de poder? Juridicamente, as obrigações dos médicos são de dois tipos: obrigações de meios e 
obrigações de resultados. Nas obrigações de meios, o profissional deverá colocar à disposição do paciente todos os recursos, além de conhecimentos atualizados, visando o melhor resultado possível; a cura ad integrum, no entanto, não pode ser prometida, pois seres biológicos não respondem matematicamente ao tratamento e resultados adversos são assim possíveis, apesar do melhor empenho da equipe médica. Se o resultado esperado não for alcançado, inexistindo negligência, imprudência ou imperícia, não poder-se-á dizer que houve descumprimento do contrato e não haverá culpa. A jurisprudência atualmente entende que a grande maioria das especialidades médicas configura obrigação de meios. Já na obrigação de resultados, entende-se contratada a obtenção de um resultado específico, e se este não é obtido, independente de culpa ou não, haverá ruptura do contrato cabendo reparação do dano. No nosso país, praticamente todos os tribunais ainda entendem que a Cirurgia Plástica estética configura uma obrigação de resultados ${ }^{8}$ e alguns têm também assim considerado a Anestesiologia $^{7,9}$, embora, felizmente, isso venha mudando recentemente ${ }^{|0,1|}$. Para os que entendem a Anestesiologia como uma obrigação de resultados, o profissional se comprometeria a anestesiar e recuperar integralmente o paciente, sem dano, desde que tenha tido a oportunidade de avaliar o doente antes da cirurgia e concluído pela existência de condições para a prática da anestesia'2. Havendo portanto culpa, em qualquer das suas modalidades, configura-se o chamado "erro médico", meIhor denominado erro de ofício ${ }^{13}$, e caberá a indenização. $\bigcirc$ "erro médico" distingue-se do erro profissional, pois este último é imputável, não à falha do profissional, mas às limitações da Medicina que nem sempre possibilitam um diagnóstico de certeza; conhecido também como
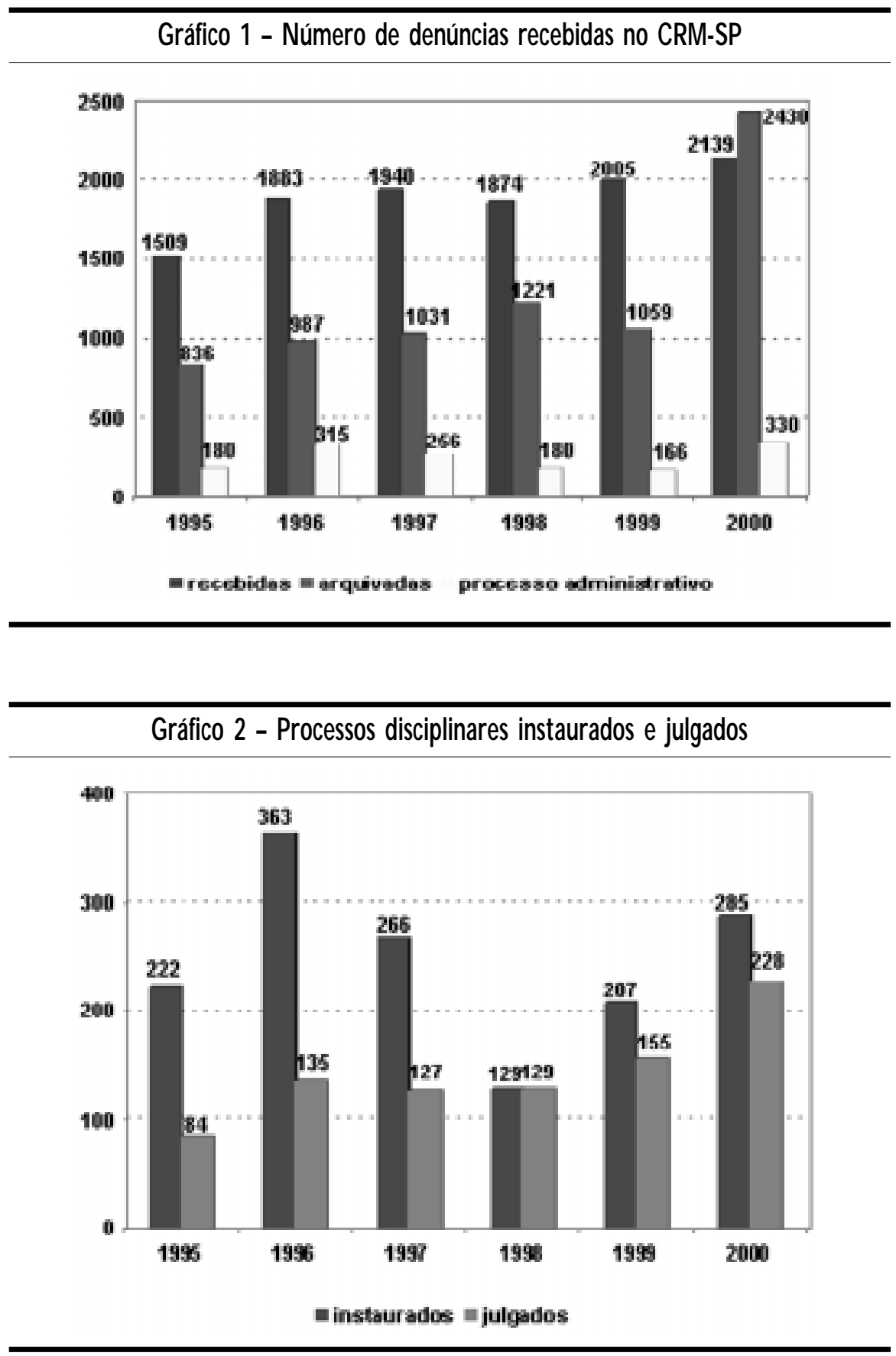

erro de diagnóstico, no seu caso é descabida a indenização.

Tratando-se de uma obrigação de meios, o eventual descumprimento do dever contratual deve ser provado pelo paciente, autor da demanda, mediante a demonstração da culpa do médico, conforme prevê o artigo 333, inciso I do
Código de Processo Civil (CPC): "O ônus da prova incumbe: I- ao autor, quanto a fato constitutivo do seu direito". Já no caso da obrigação de resultados basta ao autor demonstrar que o objetivo pactuado não foi obtido, o que é suficiente para demonstrar a ruptura do contrato e pleitear a indenização. Nesse caso, caberá ao médi- 
co provar que não agiu com culpa. É o que se convencionou chamar de inversão do ônus da prova. Nesse sentido, diz o artigo 1056 do CC: "Não cumprindo a obrigação, ou deixando de cumpri-la pelo modo e no tempo devidos, responde o devedor por perdas e danos".

O hospital, como pessoa jurídica, não realiza atos médicos, assim a ele não são aplicáveis os ditames do artigo I 545 do CC citado anteriormente. Porém, conforme o artigo I52 I, inciso III do CC: "São também responsáveis pela indenização civil: o patrão, amo ou comitente, por seus empregados, serviçais, e prepostos, no exerćício do trabalho que thes competir, ou por ocasião dele". Assim, o hospital responde solidariamente com o médico-empregado pelos erros de ofício deste durante o seu trabalho na instituição. E os médicos, pela mesma razão, respondem também pelos erros de seus assistentes e auxiliares, ou por tê-los mal escolhido (culpa in eligendo), ou por não tê-los supervisionado corretamente (culpa in vigilando $)^{14}$. Em relação aos médicos que integram o quadro clínico do hospital sem serem seus empregados, há que se distinguir duas situações: se o paciente procurou o nosocômio, tendo nele sido atendido por um integrante do corpo clínico, ainda que não empregado, respondem médico e hospital solidariamente; essa é a situação do anestesiologista que integra a equipe exclusiva de determinado hospital'2. Já se o doente procura um médico e este o encaminha ao hospital para tratamento, o contrato é só com o facultativo e o hospital não responde pela culpa dos atos deste.

Se numa ação de indenização contra um médico-empregado, este é o único réu, cabe a ele realizar o chamamento ao processo $^{15}$ do hospital como maneira de dividir as responsabilidades; tal se encontra no artigo 77, inciso II do CPC: "É admissível o chamamento ao processo: de todos os devedores solidários, quando o

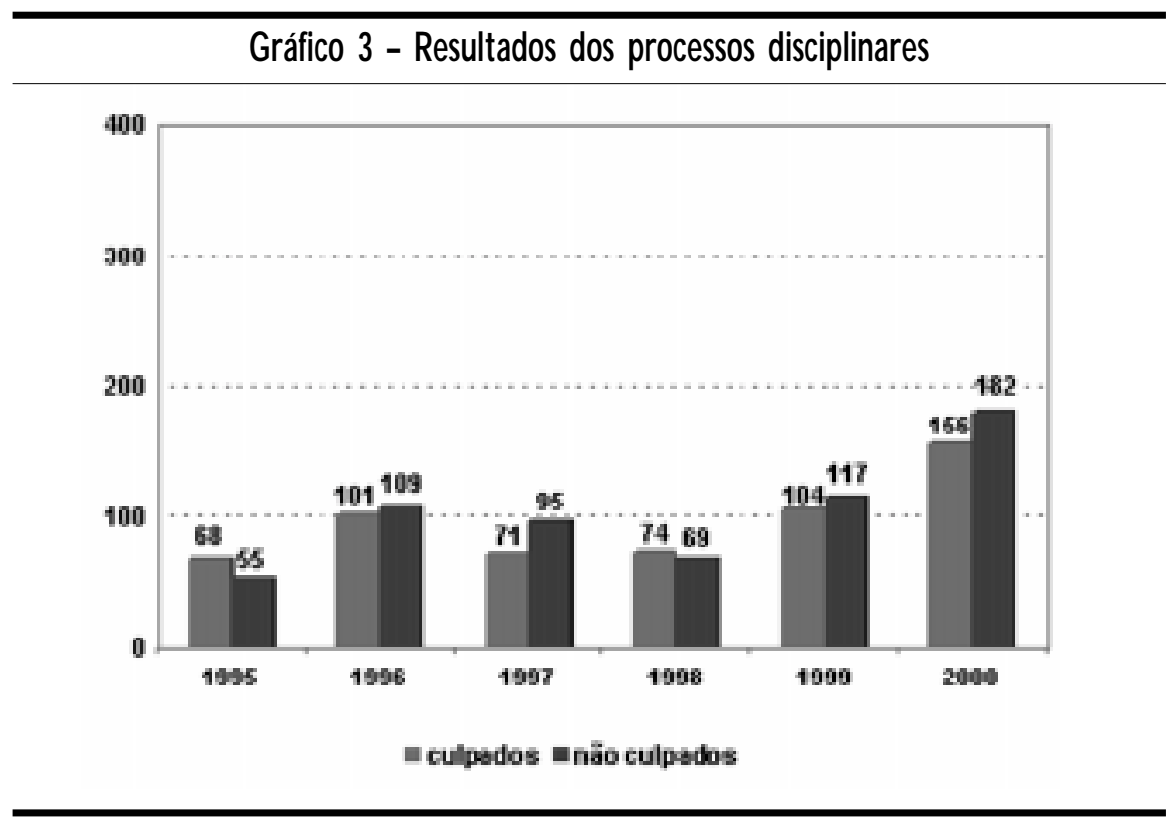

\section{Gráfico 4 - Penas aplicadas pelo CRM-SP}

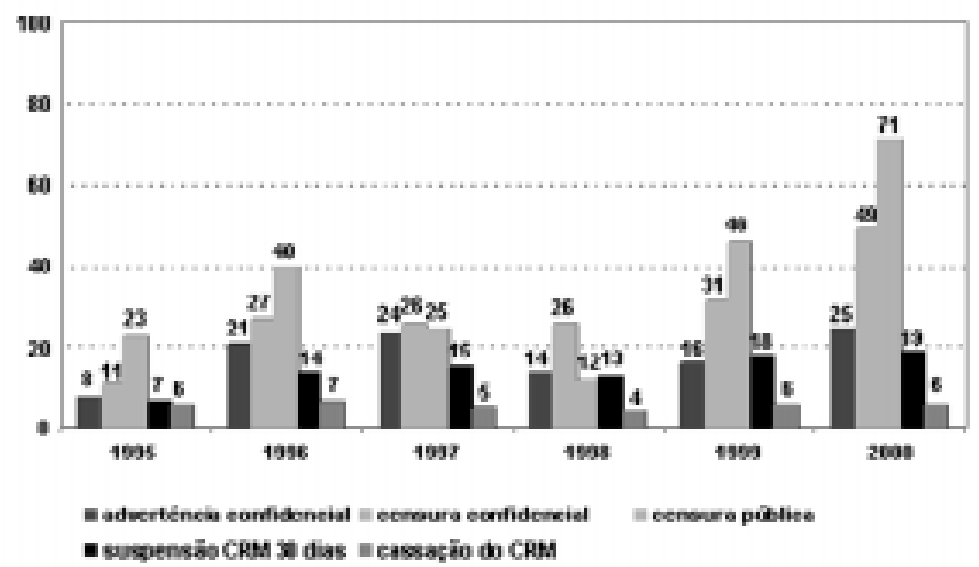

credor exigir de um ou de algum deles, parcial ou totalmente, a dívida comum".

As entidades privadas de assistência à saúde respondem solidariamente pelos erros causados por seus médicos credenciados, conforme decisão recente do Supremo Tribunal de Justiça; entendeu este tribunal haver vínculo de responsabilidade entre a companhia e o médico por ela credenciado $^{16}$. Diferentemente acontece com os seguros-saúde que dão liberdade de esco-
Iha de médicos e hospitais, reembolsando somente as despesas; nesses casos a empresa não pode ser responsabilizada pelos atos do médico escolhido pelo próprio segurado, caberá somente ao médico uma eventual indenização devida.

Até o presente, discutimos as situações que interessam à medicina privada liberal, abrangida pelas regras do Direito Privado. Diferentemente acontece nos hospitais públicos, suas fundações ou autarquias, que 
UdELSMANN A

são abrangidos pelo Direito Público, particularmente pelo Direito Administrativo. Dispõe o artigo 37 § $6^{\circ}$ da Constituição Federal (CF) sobre a responsabilidade dos hospitais públicos quanto os atos de seus empregados: "As pessoas jurídicas de direito público e as de direito privado prestadoras de serviços públicos responderão pelos danos que seus agentes, nessa qualidade, causarem a terceiros, assegurado o direito de regresso contra o responsável nos casos de dolo ou culpa". Surgem aí duas novas noções jurídicas importantíssimas: a da responsabilidade objetiva e a de direito de regresso. A CF faz menção ao princípio da responsabilidade objetiva pelos danos que seus agentes causarem a terceiros, o que significa que, demonstrado este dano, independentemente de culpa ou não, caberia a indenização pelo ente público. É a teoria do risco inerente à atividade, aliás bastante freqüente no Direito do Trabalho. Mas a doutrina hoje em dia está entendendo a possibilidade de exclusão ou atenuação da responsabilidade do Estado nos casos fortuitos ou de força maior e ainda naqueles por culpa exclusiva do próprio paciente ${ }^{12}$. Mas, havendo dolo ou culpa por parte do médico, poderá o ente público demandar, posteriormente, ressarcimento ao seu empregado; é o que se chama direito de regresso. $\mathrm{O}$ direito de regresso, juridicamente, se exerce através da denunciação da lide conforme os ditames do artigo 70, inciso III do CPC: "A denunciação da lide é obrigatória: III- àquele que estiver obrigado, pela lei ou pelo contrato, a indenizar, em ação regressiva, o prejuízo do que perder a demanda". O ente público, nesse caso, requer do médico reembolso da indenização que foi obrigado a pagar por culpa dele.

Em razão da responsabilidade objetiva das pessoas jurídicas, da indenização independente de culpa, os médicos devem ser muito cautelosos ao formar uma socieda-

de para prestação de serviços, devendo sempre, antecipadamente, consultar um advogado sobre a melhor maneira de tal empreendimento e, sendo isso necessário, formar uma sociedade civil preferencialmente a uma comercial.

\section{Gráfico 5 - As 10 especialidades com mais queixas em 1995}

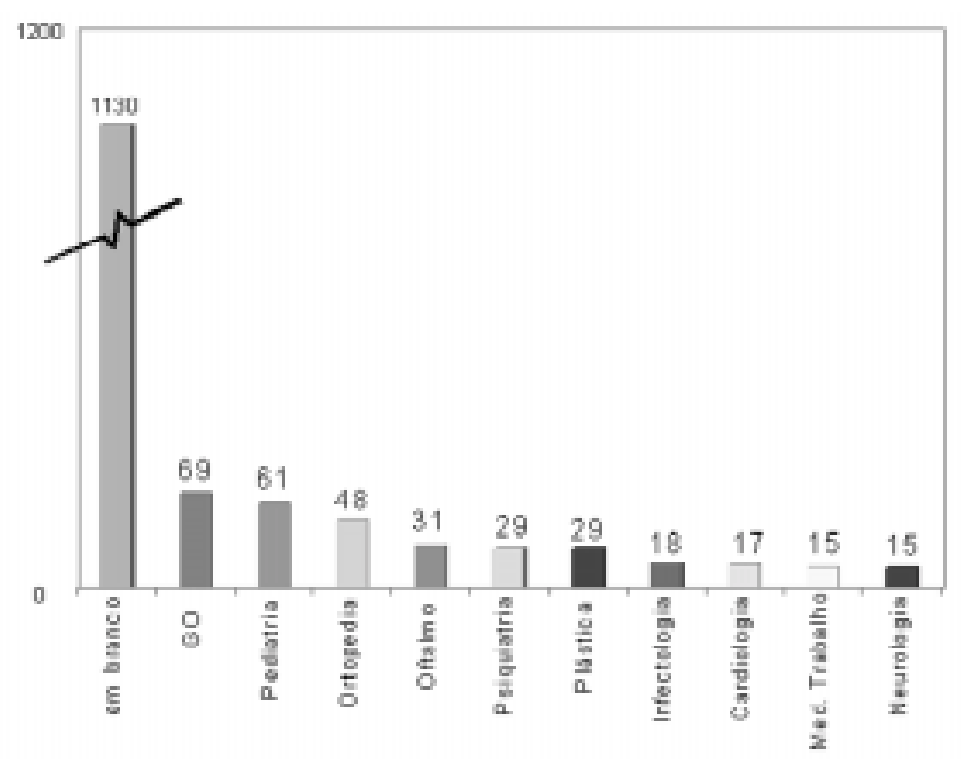

\section{Gráfico 6 - As 10 especialidades com mais queixas em 1966}

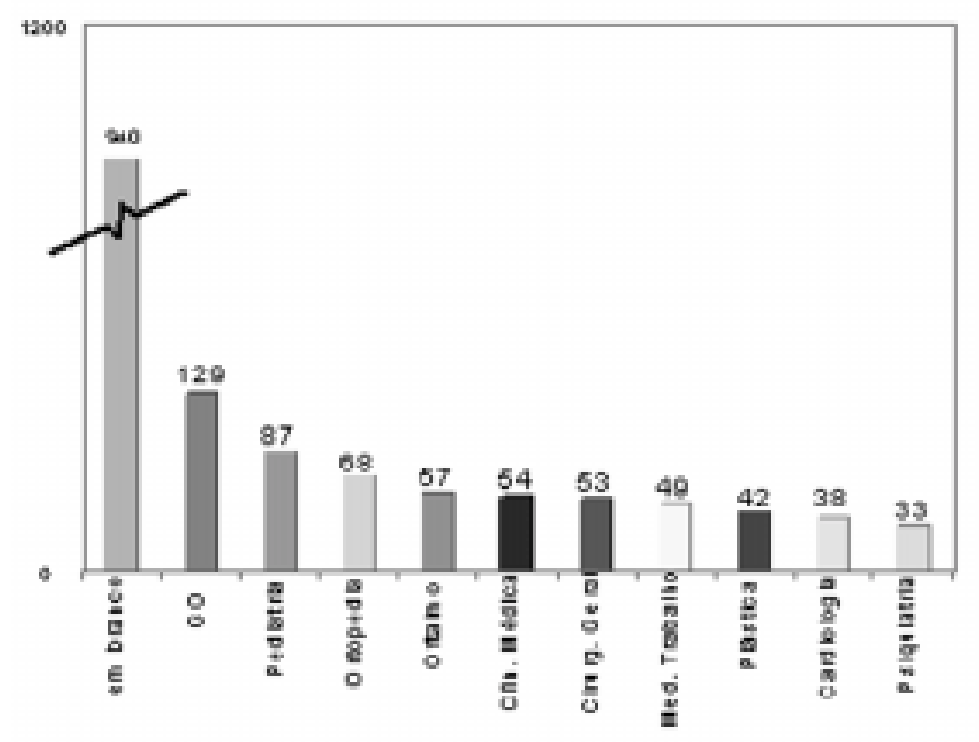

E mais, o nosso legislador, já na antiga Lei de Introdução ao Código Civil, em seu artigo $3^{\circ}$, precaveu-se contra defesas através de alegações de desconhecimento da lei, impedindo-as: "Ninguém se escusa de cumprir a lei, alegando que não a conhece". 
Em suma, é indenizável aquilo que o paciente inesperadamente despendeu em razão do ato médico para seu tratamento e recuperação (dano emergente), o quanto deixou de lucrar no seu trabalho durante a convalescença (lucro cessante) e o dano moral. Dispõe o artigo 1538 do CC: "No caso de ferimento ou outra ofensa à saúde, o ofensor indenizará o ofendido das despesas de tratamento e dos lucros cessantes até o fim da convalescença, além de lhe pagar a importância da multa de grau médio da pena criminal correspondente. § |0: Esta soma será duplicada, se do ferimento resultar aleijão ou deformidade. $\S 2$ : Se o ofendido, aleijado ou deformado, for muIher solteira ou viúva, ainda capaz de casar, a indenização consistirá em dotála, segundo as posses do ofensor, as circunstâncias do ofendido e a gravidade do efeito". E mais, se o indivíduo tornar-se inabilitado ao trabalho, mesmo parcialmente, aplica-se ainda o artigo 1539 do CC: "Se da ofensa resultar defeito pelo qual o ofendido não possa exercer o seu ofício ou profissão, ou se Ihe diminua o valor do trabalho, a indenização, além das despesas do tratamento e lucros cessantes até o fim da convalescença, incluirá uma pensão correspondente à importância do trabaIho, para que se inabilitou, ou da depreciação que ele sofreu".

A indenização do dano moral, da dor pelo sofrimento imprevisto por eventual culpa do médico, leva em conta a natureza deste dano, a situação econômica dos interessados, o impacto negativo na vida do paciente ${ }^{17}$ e é a que se presta às maiores celeumas. Está prevista na Constituição Federal no artigo 5, incisos $\checkmark$ e $X$, mas seu montante não está legalmente previsto e ficará ao arbítrio do juiz' conforme o artigo 1553 do CC:

\section{Gráfico 7 - As 10 especialidades com mais queixas em 1997}

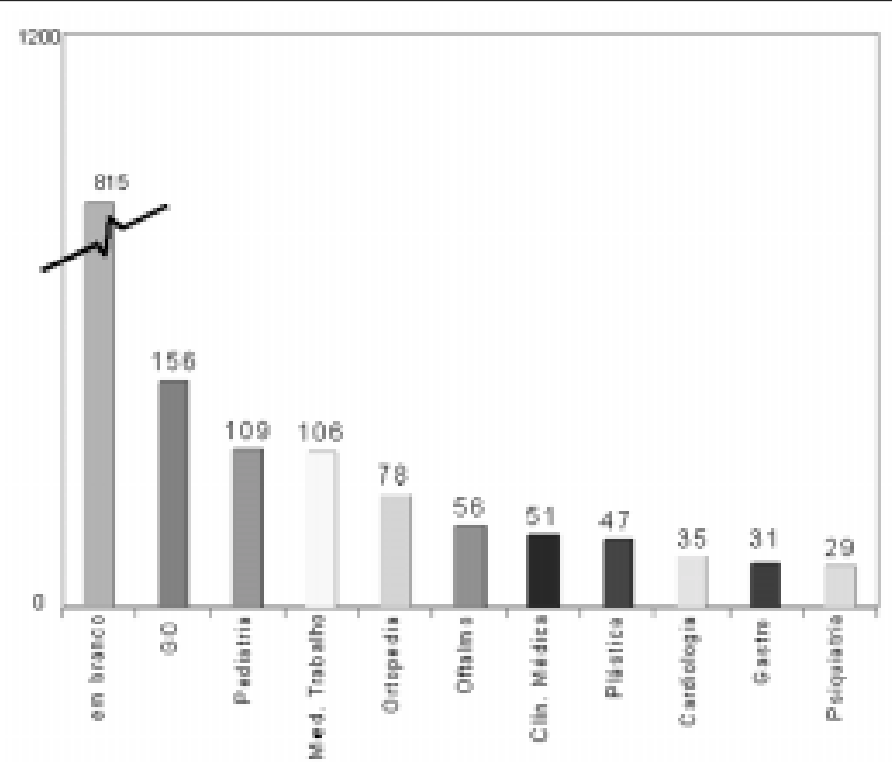

\section{Gráfico 8 - As 10 especialidades com mais queixas em 1998}

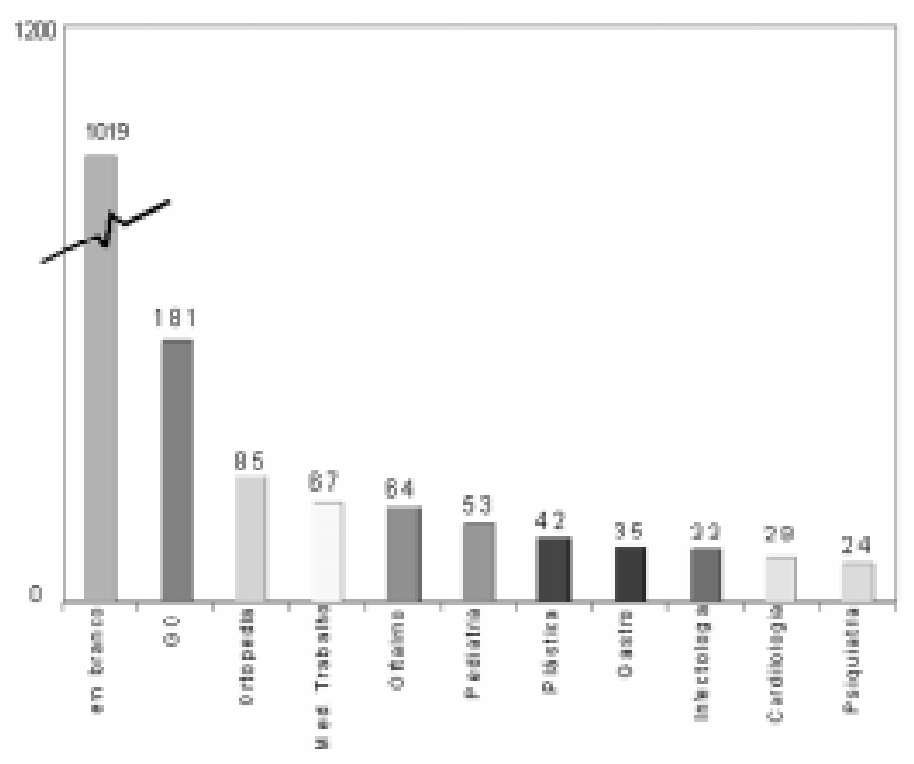

"Nos casos não previstos neste capítulo (das liquidações das obrigações), se fixará por arbitramento a indenização".

Por último, é bom lembrar o princípio da prescrição, que é a perda da pretensão punitiva pelo decurso do tempo sem seu exercício pelo interessado; decorrido um tempo determinado o acusado não mais poderá ser punido. Segundo o Código Civil atual, prescreve em um ano o direito do médico em acionar o paciente inadimplente para cobrança de seus hono- 
UdELSMANN A

rários (artigo 178, § 60, inciso IX); após um ano da prestação do serviço não poderá ele mais reivindicar judicialmente o eventual preço combinado e não honrado. lá o paciente tem o benefício legal de um prazo de 20 anos para acionar o médico por um suposto erro médico (artigo 177), só depois disso ocorrendo a prescriçãa. Isto nos obriga, atualmente, a mantermos por esse período toda a documentação relativa a nossos pacientes. Porém, e felizmente, foi recentemente sancionado o novo Código Civil que entrará em vigor a partir do próximo ano de 2003, nele encontramos uma substancial alteração legal que, em muito, beneficia os médicos: segundo o seu artigo $200 \S 3^{\circ}$ prescreverá em 3 anos a pretensão de reparação civil a partir do ano que vem. E ainda, segundo o $\S 5^{\circ}$ do mesmo artigo, terá o médico cinco anos para cobrar os seus honorários.

\section{Responsabilidade Penal}

A responsabilidade penal se origina pela ação ou omissão de um fato típico antijurídico com nexo de causalidade e um dano penal. Ao contrário da lei civil, são considerados ilícitos penais (crimes e contravenções) somente aqueles especificamente enumerados na lei: no Código Penal (CP), na Lei de Contravenções Penais e alguns outros em leis esparsas. Há, então, absoluta necessidade que $\mathrm{o}$ ato cometido esteja descrito com precisão na lei ${ }^{18}$ para que o agente possa ser responsabilizado criminalmente e penalizado conforme prescreve o artigo $5^{\circ}$, inciso XXXIX da CF e o artigo $1^{\circ}$ do CP que têm a mesma redação: "Não há crime sem lei anterior que o defina. Não há pena sem prévia cominação legal".

Diz o artigo 18 do CP quais são, genericamente, os tipos de crimes possíveis: "Diz-se o crime: I- doloso quando o agente quis o resultado ou assumiu o risco de produzi-lo; II- culposo, quan-

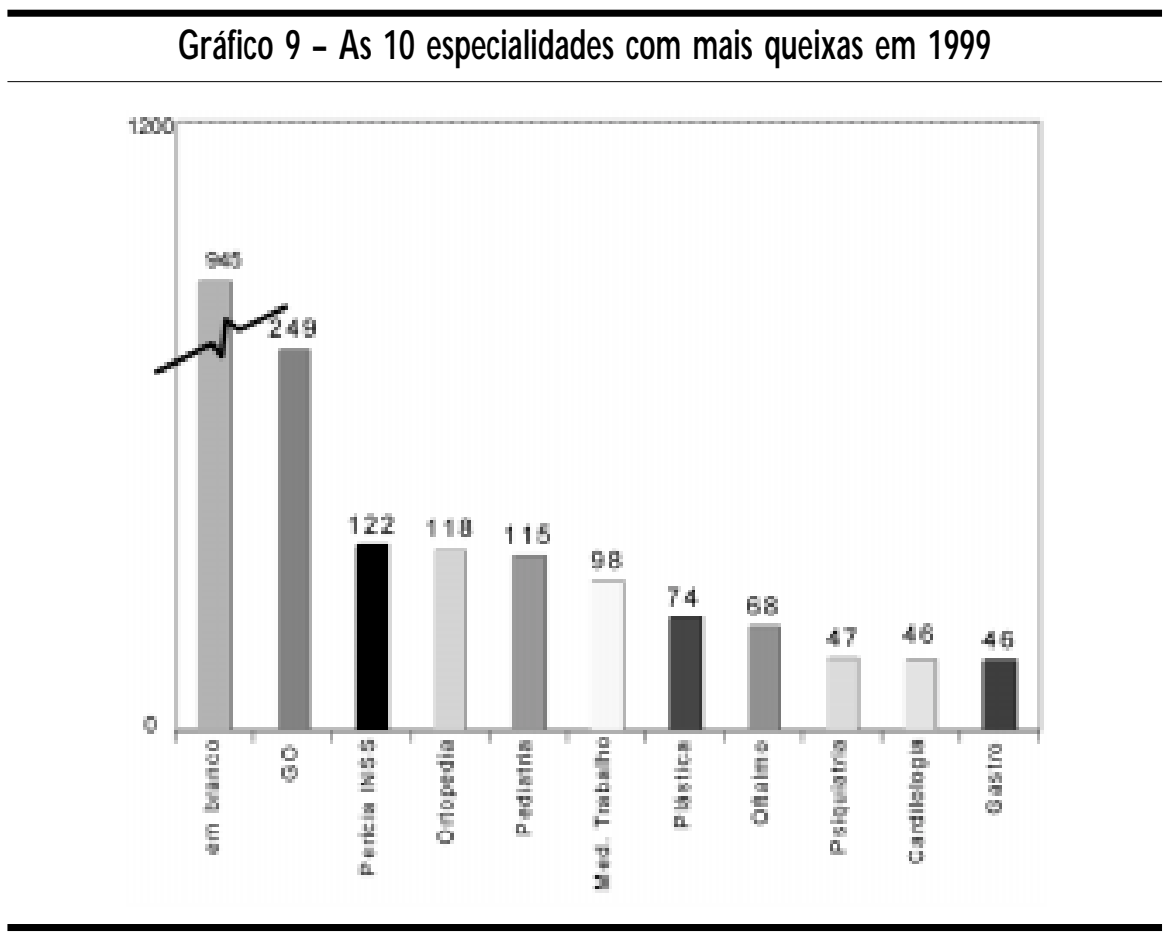

\section{Gráfico 10 - As 10 especialidases com mais queixas em 2000}

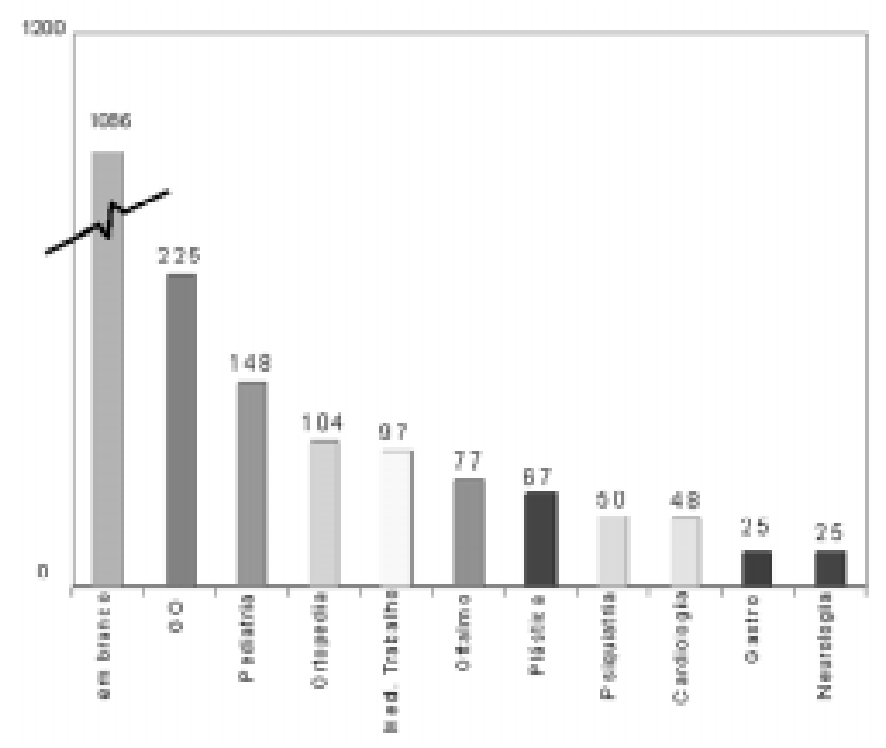

do o agente deu causa ao resultado por imprudência, negligência ou imperícia". No crime doloso, a vontade do agente é de produzir o resultado danoso ou, ao menos, assumiu ele o risco dessa possi- bilidade ocorrer (dolo eventual). Já no crime culposo, a vontade do agente não era de causar dano, mas isso veio a ocorrer em razão de imprudência, negligência ou imperícia. 
As penas aplicadas podem ser, conforme o artigo 32 do $C P$, privativas de liberdade, restritivas de direitos ou ainda multa e variam conforme a gravidade do crime praticado. Nos crimes culposos contra a vida e nas lesões corporais, segundo o $\S 4^{\circ}$ do artigo I21 e o $\$ 7^{\circ}$ do artigo 129 do CP, a pena será aumentada de um terço se 0 crime resulta de inobservância de regra técnica de profissão, o que pode ser o caso de um erro médico. A prática de ilícito penal pode levar a indenização civil para reparação do dano e, em caso de condenação criminal definitiva, na justiça civil, discutir-se-á somente o montante da indenização devida (artigo 584, inciso II do CPC + artigo 63 do (PP) e não mais se o médico é culpado ou não.

Mas a absolvição na justiça criminal não significa simultaneamente absolvição civil. O Código Civil, em seu artigo 1525 diz: "A responsabilidade civil é independente da criminal; não se poderá, porém, questionar mais sobre a existência do fato, ou quem seja seu autor, quando estas questões se acharem decididas no crime". O mesmo diz o artigo 66 do CPP: "Não obstante a sentença absolutória no juízo criminal, a ação civil poderá ser proposta quando não tiver sido, categoricamente, reconhecida a inexistência material do fato".

No exercício da Medicina, o médico pode cometer crimes dolosos. A prática do aborto ainda é um crime na nossa legislação, excetuando-se as circunstâncias excludentes descritas no artigo 128 do CP (para salvar a vida da gestante ou em caso de estupro). Se um anestesiologista participa de um aborto criminoso, embora não seja ele que realize a curetagem, estará ele incorrendo nas penas do artigo 29 do CP que trata do concurso de pessoas. "Quem, de qualquer modo, concorre

\section{Gráfico 11 - As 10 especialidades com mais queixas no primeiro semestre do 2001}

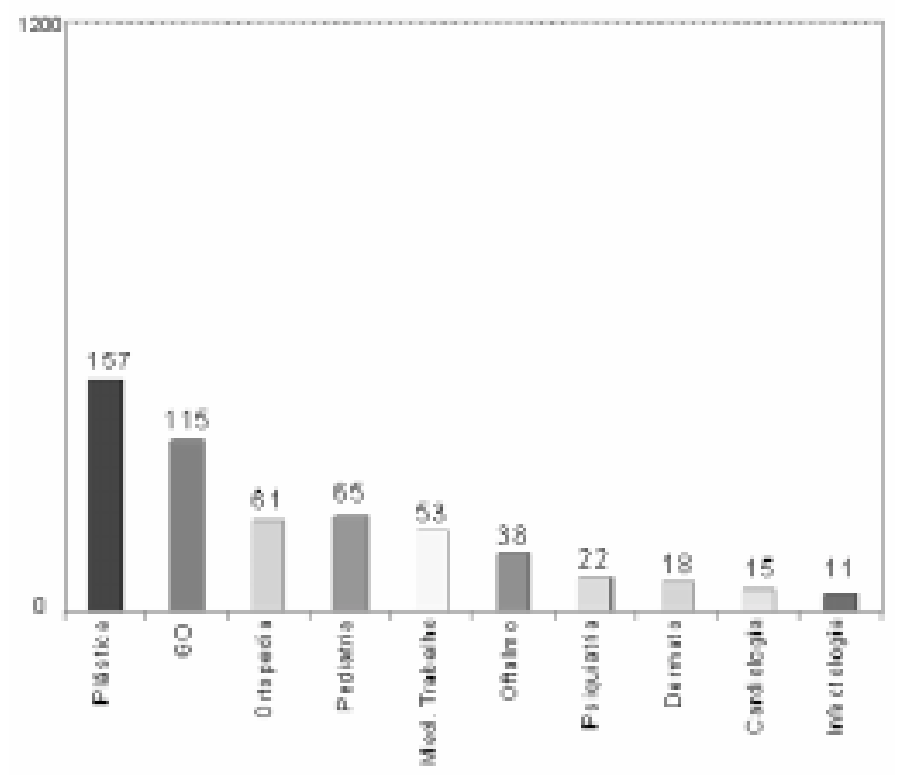

para o crime incide nas penas a este cominadas, na medida da sua culpabilidade". São também crimes possíveis de serem praticados por médicos no exercício da sua profissão segundo o Código Penal: o auxílio ao suicídio (art. 122), a omissão de socorro à pessoa ferida (art. 135), a exposição da vida ou da saúde de outrem a perigo direto e iminente (art. 132), o constrangimento a tratamento ou cirurgia contra a vontade do paciente (art. 146), a revelação de segredo profissional sem justa causa (art. 154), a omissão de notificação de doença compulsória (art. 269), o charlatanismo (art.284). A Lei das Contravenções Penais em seu artigo 66, inciso II penaliza ainda o caso de: "Deixar de comunicar a autoridade competente: II- crime de ação pública de que teve conhecimento no exercício da medicina ou de outra profissão sanitária, desde que a ação penal não dependa de representação e a comunicação não ex- ponha o cliente a procedimento criminal". Por fim, o Código de Processo Penal, em seu artigo 207, proíbe o médico de depor como testemunha no seguinte caso: "São proibidas de depor as pessoas que, em razão de função, ministério, ofício ou profissão, devam guardar segredo, salvo se desobrigadas pela parte interessada, quiserem dar o seu testemunho". Nesta última circunstância, deverá, no entanto, o médico porém comparecer em juízo e declinar as razões que o impedem de depor ${ }^{19}$ de acordo com os artigos 102 a 109 do Código de Ética Médica. Sobre o artigo 135 do CP acima descrito, é interessante lembrar que o Tribunal de Alçada Criminal de São Paulo já confirmou a aplicação da pena nele prevista a familiares que negaram autorização para transfusão de sangue por motivos religiosos ${ }^{20}$.

Mas no exercício da Medicina os crimes culposos são os que têm maiores possibilidades de ocorrer. São eles 
o homicídio culposo e as lesões corporais culposas, que integram uma agravante se realizados por médicos no exercício da sua profissão:

Homicídio - art. 121: Matar alguém

$\S 30$ : se o homicídio é culposo

Pena - detenção, de I a 3 anos

$\S 4^{\circ}$ : no homicídio culposo, a pena é aumentada de um terço, se o crime resulta de inobservância de regra técnica de profissão, arte ou ofício...

Lesões corporais - art. 129: Ofender a integridade corporal ou a saúde de outrem

$\S 60$ : se a lesão é culposa

Pena - detenção, de 2 meses a I ano

$\S 7^{\circ}$ : aumenta-se a pena de um terço, se ocorrer qualquer das hipóteses do art. $121 \S 4^{\circ}$.

Praticando então um ato médico, se dele resultar a morte ou lesão corporal no paciente, tendo o médico agido com imprudência, negligência ou imperícia, incorrerá ele nas penas acima previstas, podendo ainda ser reclamado na justiça civil a ressarcir financeiramente o dano causado.

É conveniente lembrar que, em matéria penal, só podem ser réus as pessoas físicas, ou seja, o médico no que nos interessa, não cabendo processo contra o hospital, seguro saúde ou a empresa que emprega o médico.

Nos crimes ditos materiais, ou seja, nos que deixam vestígios, o Código de Processo Penal (CPP) exige a execução de perícia segundo seu artigo I58: "quando a infração deixar vestígios, será indispensável o exame de corpo de delito, direto ou indireto, não podendo supri-lo a confissão do acusado". O exame de corpo de delitose materializa na perícia, e esta poderá ser realizada diretamente na vítima, ou indiretamente através de documentos comprobatórios (prontuário, etc, daí o interesse em ter tudo isso muito bem escriturado, documentado). Sem a perícia há nulidade insanável do processo ${ }^{21,22}$ conforme o ar- tigo 564, inciso III, alínea b do CPP: "A nulidade ocorrerá nos seguintes casos: IIIpor falta das fórmulas ou dos seguintes termos: b) o exame de corpo de delito nos crimes que deixam vestígios, ressalvado o disposto no art. 167".

A exemplo da lei civil, o legislador penal também precaveu-se contra as alegações de ignorância da lei no artigo 21 do CP: "O desconhecimento da lei é inescusável. O erro sobre a ilicitude do fato, se inevitável, isenta de pena; se evitável, poderá diminuila de um sexto a um terço".

A lei penal tem também seus prazos de prescrição e este variam conforme o máximo da pena aplicável conforme o artigo 109 do CP. No caso do homicídio culposo, a prescrição se dá em 8 anos e na lesão corporal em 4 anos, mas havendo a agravante do art. $121 \S 4^{\circ}$, as penas serão aumentadas de $1 / 3$ e os prazos prescricionais podem assim ser maiores.

\section{Responsabilidade Ética}

O processo civil busca a reparação do dano material, o processo penal a proteção da sociedade, já o processo ético junto ao Conselho Regional de Medicina visa a disciplina da conduta profissional médica. O processo ético é de natureza moral com cunho administrativo, mas pode, em última instância, ser contestado juridicamente, pois a Constituição Federal garante isso em seu artigo 50, inciso XXXV: "a lei não excluirá da apreciação do Poder Judiciário lesão ou ameaça a direito". A lei 3.268/57 que dispõe sobre os Conselhos de Medicina, em seu artigo 22, § $5^{\circ}$ também confirma a possibilidade de recurso à justiça comum: "além do recurso previsto no parágrafo anterior, não caberá qualquer outro de natureza administrativa, salvo aos interessados a via judiciária para as ações que forem devidas".

As regras éticas, em geral, não têm caráter impositivo por carecerem de sanções legais; porém, se o Código de Ética Médica é uma resolução do Conselho Federal de Medicina ( $n^{\circ}$ 1246/88) sem força de lei, suas sanções, no entanto, estão previstas na Lei 3.268/57 em seu artigo 22, e isso Ihes dá força impositiva com caráter jurídico: "As penas disciplinares aplicáveis pelos Conselhos Regionais aos seus membros são as seguintes: a) advertência confidencial em aviso reservado; b) censura confidencial em aviso reservado; c) censura pública em publicação oficial; d) suspensão do exercício profissional até 30 dias; e) cassação do exercício profissional, ad referendum do Conselho Federal". Essa mesma lei, em seu artigo 2I, § único, confirma ainda o óbvio: "O poder de disciplinar e aplicar penalidades aos médicos compete exclusivamente ao Conselho Regional, em que estavam inscritos ao tempo do fato punível em que ocorreu, nos termos do art. 18 § único - § único: a jurisdição disciplinar estabelecida neste artigo não derroga a jurisdição comum quando o fato constitua crime punido em lei".

A apuração da responsabilidade éticodisciplinar, ao contrário do processo civil e do processo criminal, se faz em "segredo de justiça" segundo o artigo 38 do Código de Processo Ético-Profissional (resolução CFM no 1.464/96): "O julgamento disciplinar far-se-á a portas fechadas, sendo permitida somente a presença das partes e seus procuradores, até o encerramento da sessão". Esse segredo é, no entanto, relativo, pois a justiça comum, tanto civil como criminal, pode requisicionar cópias do processo para instruir demandas cíveis ou criminais, utilizando-as como meios de provas. A justiça comum não pode porém apreciar a questão de mérito ético-disciplinar que, legalmente, é da competência exclusiva dos Conselhos de Medicina segundo o artigo $2^{\circ}$ da lei 3.268/57: "O Conselho Federal e os Conselhos Regio- 
nais de Medicina são os órgãos supervisores da ética profissional em toda a República, e, ao mesmo tempo, julgadores e disciplinadores da classe médica, cabendo-lhes zelar e trabalhar por todos os meios ao seu alcance, pelo perfeito desempenho ético da medicina e pelo prestígio e bom conceito da profissão e dos que a exerçam legalmente". Os processos éticos estão também sujeitos à prescrição segundo o Código de Processo Ético-Profissional em seu artigo 51: "A punibilidade por falta ética, sujeita a processo ético-profissional, prescreve em 5 anos, contados a partir da data do conhecimento do fato".

Assim, em razão das sanções legais impostas nos casos das infrações éticas e do acesso às decisões dos Conselhos de Medicina pela justiça comum, as quais são freqüentemente solicitadas, é de todo interesse dos médicos com processos éticodisciplinares, que os mesmos sejam criteriosamente acompanhados, de maneira a não dar margens a outras demandas, por vezes bem mais vultuosas.

Em estatística solicitada ao CRM-SP, notamos que o número de queixas apresentadas tem aumentado progressivamente nos últimos 5 anos, conforme se observa no gráfico 1.

A discrepância entre o número de queixas recebidas e a somatória das arquivadas e das transformadas em processos administrativos, deve-se ao fato de muitas dessas queixas terem a sua decisão proferida em ano posterior ao da sua apresentação.

O gráfico 2 mostra o número de processos disciplinares instaurados e os julgados; novamente a diferença aparente dos números do gráfico anterior deve-se a que nem todos processos administrativos tornam-se disciplinares e muitos não são julgados no ano da sua instauração.

O gráfico 3 mostra o resultado dos processos disciplinares no CRM-SP. Mais uma vez a diferença entre os números deve-se a que processo são julgados, às vezes, mais de um colega.

O gráfico 4 mostra as penas previstas no art. 22 da Lei 3.268/57 e sua aplicação nos últimos 5 anos. Com exceção da cassação do CRM, nota-se um aumento progressivo do número de penas aplicadas.

A seguir, nos gráficos de 5 a 11 , mostramos as 10 especialidades médicas mais visadas por ano e o número de queixas recebidas. Atenção deve ser dada às "queixas em branco" que envolvem ou mais de uma especialidade por queixa, ou não exatamente determinada especialidade; tal noção deve impedir uma falsa segurança que, talvez, a ausência nessa estatística causaria.

\section{CONCLUSÕES}

Os médicos estão hoje, freqüentemente, sujeitos a acusações de "erro médico"; como em Medicina o melhor remédio é a prevenção, a boa e criteriosa prática profissional ainda é a melhor vacina contra essa epidemia que grassa entre nós. Devemos incentivar a realização de Termo de Ciência e Consentimento para os vários atos médicos, hoje exigência do Código de Defesa do Consumidor; o constrangimento que isso pode de início causar deve diminuir, paulatinamente, na medida em que se tornar costumeiro, ou mesmo obrigatório. $O$ médico deve sempre preencher o prontuário de maneira clara e com letra legível; juizes vêem com maus olhos "hieróglifos" e não tendem a interpretá-los em benefício do médico.

Finalmente, frente a uma ação por "erro médico", três regras são importantes: a primeira diz respeito ao prazo para a defesa que, segundo o artigo 297 do CPC, é de somente 15 dias. A fase inicial da defesa, que se materializa na "contestação", numa área técnico-científica tão es- pecífica como a Medicina, é freqüentemente difícil e trabalhosa, o médico não deve perder tempo, procurando rapidamente um advogado da sua confiança assim que receber a citação que é a comunicação legal da existência de uma ação contra ele, em geral, feita por via postal. Segunda: é regra importante no CRM não acusar terceiros, outros colegas; tal prática é muito mal vista nos Conselhos de Medicina e deve ser evitada, pois pode causar mais prejuízos do que benefícios. E a terceira, mas talvez a mais importante das condutas, seja a de não praticar a autodefesa, que aliás é somente possível no CRM. A auto-defesa está para o Direito como a auto-medicação está para a Medicina, um desastre. Se somente os médicos podem e devem tratar ou medicar os seus pacientes, da mesma maneira, somente os advogados têm a capacitação e só eles devem se ocupar da defesa dos médicos.

\section{Summary}

\section{Civil, Criminal and Ethical liability OF MEDICAL DOCTORS}

In the last years doctors have been the target of a growing number of civil, criminal law suits, as well as ethical procedures. Medicine is a widely targeted career, not only owing to its inherent risks, but also owing to a mistaken approach of the Judiciary Power about the obligations of medical doctors. Decisions of the Medical Board in ethical procedures have an impact in civil and criminal justice and therefore should be followed closely. The purpose of this review is to provide a wide view from a doctor-lawyer perspective of cases involving civil, criminal liability of anesthesiologists as well as ethical procedures against them, in an effort to make them comprehensible to doctors.

After a brief historical introduction civil liability foundations and legal articles are examined. Responsibilities of doctors, hos- 
Udelsmann A

pitals and health insurance providers are discussed separately, as well as reparation mechanisms. Crimes possible to occurduring medical practice and respective penalties are described; the direct relationship between crime and civil reparation is demonstrated. The administrative nature of ethical procedure is described, emphasizing that the legal character of its penalties often serve as grounds for civil and criminal justice decisions.

Prevention is still the best medicine. Good medical practice and a good medical-patient relationship are still the best ways to minimize lawsuitsand theirrepercussions. Doctorsshould have someknowledge ofjuridica/mechanismsin lawsuits and ethical procedures, but should not take defense initiatives without prior consultation of an attorney. Civil, criminal and ethical liability of physicians. [Rev Assoc Med Bras 2002; 48(2): 172-82]

Kerwords: Physician. Liability: civil, criminal, ethical.

\section{ReferênCiAS}

I. Valler WA. Reparação do dano moral no direito brasileiro. 3a. ed. Campinas: E.V. Editora; 1995. p.43-57.

2. Súmula 37 do Supremo Tribunal de Justiça

3. Diniz MH. Título VII - Das obrigações por atos Ilícitos. In: Diniz MH. Código civil anotado. 2a. ed. São Paulo: Ed. Saraiva; 1996, p.9954-73.

4. Negreiros AAF, Negreiros CC. Verificação da culpa do anestesiologista. Rev Bras Anestesiol 1993; 43:34I-4

5. Jesus DE. Título II - Do Crime. In: Jesus DE. Código penal anotado. 6a. ed. São Paulo: Ed. Saraiva; 1999. p.29-95.

6. Parecer $n^{\circ}$ 128. Revista de Jurisprudência do Tribunal de Justiça do Rio Grande do Sul.

7. Stoco R. Responsabilidade dos médicos. In: Stoco R. Responsabilidade civil e sua interpretação jurisprudência. 4a. ed. São Paulo: Ed. Revista dos Tribunais; 1999. p.286-307

8. Parecer $n^{\circ}$ |70/I 45. Revista Jurídica.

9. Kfouri Neto M. Responsabilidade civil em anestesiologia. In: Kfouri Neto M. Responsabilidade civil do médico., 3a. ed. São Paulo: Ed. Revista dos Tribunais; 1998. p. I36-49.

10. Romanello Neto J. Anestesista. In: Responsabilidade civil dos médicos. São Paulo: Ed. Jurídica Brasileira; 1998. p. 129-32.

II. Albuquerque AC. Decisão do Tribunal de Alçada do Paraná define obrigações do anestesista. Arquivo do Conselho Regional de Medicina do Paraná, 1999; 16:65-6.

12. Aguiar Junior RR. Responsabilidade civil do médico. RJ 23I - jan.; 1997. p. I22-50.

13. Ribeiro JB, Ribeiro NB. A tradução da palavra inglesa "mal practice". Rev Bras Anestesiol, 1990; 40:224-5.

14. Ribeiro JB. Aspectos médico-legais da Anestesiologia. Rev Bras Anestesiol, 1991; 41:6977.

15. Nery Junior N, Nery RMA. Seção IV- Do chamamento ao processo. In: Nery Junior N, Nery RMA. Código de processo civil comentado. 2a. ed. São Paulo: Ed. Revista dos Tribunais; 1996. p.458-62.

16. STJ REsp 138.059-MG, Rel. Min. Ari Pargendler, julgado em |3/3/200|

17. Valler $W$. Da avaliação do dano moral. In: Valler W. A reparação do dano moral no direito brasileiro. 3a. ed. Campinas: E.V. Editora, 1995. p.263-70.

18. Jesus DE. Título I - Da aplicação da Lei Penal. In: Jesus DE. Código penal anotado. 6a. ed. São Paulo: Ed. Saraiva; 1999. p. I-29.

19. RHC 3.946-DF-DJU de 1-7-96

20. TACrimSP, HC 184.642, RT 647:302

21. Revista dos Tribunais 561/329

22. Revista dos Tribunais 672/388

Artigo recebido: 25/10/200 I Aceito para publicação: 31/01/2002

\section{MAGEM EM MEDICINA}

Participe da nova seção da Ramb. É um espaço aberto ao leitor, que poderá enviar material de interesse educativo como fotos, ilustraçães e exames, acrescido de três linhas explicativæs contendo ainda nome do autor e serviço onde foi realizado. 0 material poderá ser enviado para a

Rua São Carlos do Pinhal, 324 - Cep 01333-903 S Paulo - SP - E-mail: ramb@amb.org.br 